\title{
Effects of mancozeb on citrus rhizosphere bacterial community
}

\author{
Zhendong Huang ${ }^{1 *}$, Peng Wang ${ }^{1}$, Zhanxu Pu ${ }^{1}$, Lianming Lu ${ }^{1}$, Guoqing Chen ${ }^{1}$, Xiurong $\mathrm{Hu}^{1}$, \\ Amna Fayyaz ${ }^{2}$, Yunpeng Gai ${ }^{3}$
}

1 The Citrus Research Institute of Zhejiang Province, Taizhou City, Zhejiang Province 3018020, China

2 Department of Plant Pathology, University of California, Davis 95616, CA USA

3 Key Lab of Molecular Biology of Crop Pathogens and Insects, Ministry of Agriculture, Institute of Biotechnology, Zhejiang University, Hangzhou 310058, China

* Correspondence: Zhendong Huang, hyhzd121505@163.com, Tel:+8613957609510. Taizhou3108020, China.

\begin{abstract}
Mancozeb is extensively used fungicide to prevent citrus melanose in most Asian countries, especially in China. So far, however, there have been no reports of thet effect of Mancozeb on the citrus rhizosphere bacterial community. Therefore, this comparative experiment defined the genomic and functional related to community and soil health of 2-years old Citrus unshiu Marc. rhizosphere through amplicon sequencing and chemical analysis. This study evaluated the effect of mancozeb on the chemical properties of citrus-cultivated soil and the richness and diversity of rhizosphere bacterial community. We also investigated the abundance response of rhizosphere bacterial groups to $0,2,4,6$ and 8 times application of $2 \mathrm{~g}$ mancozeb (active ingredient content, ai.) 600 times diluted with water. Our data revealed that the abundance of rhizosphere-associated bacterial species increased significantly after planting citrus. The relative abundance of Candidatus, Saccharibacteria, Parcubacteria, and Proteobacteria increased with the increase in mancozeb watering times. Meanwhile, the abundance of Nitrospirae decreased with the increase in mancozeb application times. The findings indicated that the chemical properties of the soil and the richness and diversity of rhizosphere bacterial community did not significantly differ across the mancozeb gradients in soil.
\end{abstract}

Keywords: Citrus, root rhizosphere, mancozeb, bacteria community ,diversity.

\section{Introduction}

Plants rhizosphere harbors a high diversity of microorganisms which mostly include bacteria, archaea, and fungi. [1]. Bacteria are the most dominant domain and accounted for more than $99 \%$ of the citrus root-associated microbiome, The rhizosphere bacteria play important role for benefit plants by preventing pathogenic infection and assisting in nutritional acquisition from the soil, as crucial components of agricultural ecosystems involve primary soil processes, soil fertility, and subsequent crop productivity [2-4].

Citrus is perennial plants, as a main fruit crops are grown in many tropical and subtropical regions worldwide [5], it has recently been hampered by environmental and disease pressures [6], Pesticides are the most important chemicals for enhancing the quality and the quantity of agricultural products [7]. Modern citrus industry largely relies on the wide application of pesticides. However, long-term, and over-application of pesticides not only kill pests and plant pathogens but 
also have serious effects on soil ecology that may cause changes in or the erosion of beneficial or plant probiotic soil microflora [8], In addition, the continued application of pesticides will influence a series of soil properties, including soil nutrient content, $\mathrm{pH}$, organic carbon $(\mathrm{C})$, moisture, and diversity of microbial communities, which is an indicator of pesticide toxicity in agricultural soils [9-11], it needs to pay attention to the detrimental effects of pesticides, especially when the same pesticide is continuously being used for crop protection [12-13].

Citrus melanose is an important disease caused by Diaporthe citri that affects a variety of citrus cultivars and reduces the commercial value of fresh fruit [14]. This disease is prevalent in most citrus-growing areas in more than 80 countries and regions, including 7 largest citrus-producing countries in the world [15]. Citrus melanose can persistently infect citrus in different stages, especially from the flowering period to fruit turning color stage. Therefore, a large amount of chemical fungicides are continuously being used to avoid severe damages throughout the whole growing season. It is time-consuming for citrus growers to control this disease because prevention is much better than cure. The citrus trees must be sprayed with fungicides at least four or five times every year. In most Asian countries such as China, Japan, Korea, and India, $80 \%$ wettable powder of mancozeb has been considered as one of the most effective measures to control citrus melanose via spraying from May to August [16-18]. The high concentration and spraying times of mancozeb are very helpful for the continuous control of the disease. In some orchards, mancozeb was sprayed more than 8 times a year at a concentration of $4-8 \mathrm{~kg} \mathrm{ha}^{-1}$ (ai) to control citrus melanose.

Mancozeb is a very important protective non-systemic dithiocarbamates, which is a broad-spectrum fungicide. However, mancozeb is not persistent in the soil under aerobic conditions, and it is easy to be chemically and microbially degraded into ethylene thiourea and ethylene urea, and finally converted into $\mathrm{CO}_{2}$. Ethylene thiourea may persist longer in soils. Fungicides and degradation product usually have toxic environmental effects and can inhibit the sensitive communities of soil bacteria, thus leading to a decrease in bacterial diversity. For instance, repeated applications of the fungicide carbendazim had a transiently harmful effect on the functional diversity of soil culturable microbial communities and the first application significantly decreased the Shannon-Wiener index [19-20]. In addition, Sang and Kim indicated that application of metalaxyl could reduce both bacterial and fungal communities [21]. Previous studies about mancozeb are mainly focused on the effect of soil physicochemical properties, soil microbial populations, soil biological processes, and enzyme activities in soil, $\mathrm{C}$ and $\mathrm{N}$ mineralization after treatment with mancozeb [22-24].

To our knowledge, the effect of mancozeb residues in the citrus orchard soil microbial diversity by high-throughput sequencing has not been reported. Here, we performed this comparative experiment and defined the genomic and functional features of the citrus rhizosphere from amplicon sequencing of the community, evaluating the impact of mancozeb on the citrus orchard soil rhizosphere bacteria. In our work, the objectives of the present study are: (1) to study the effects of mancozeb on soil chemical properties; (2) to investigate the effect of mancozeb on the rhizosphere bacterial community of citrus soil; and (3) to evaluate the impact of mancozeb application times on the soil rhizosphere bacterial community in citrus orchard.

\section{Materials and Methods}

\subsection{Experiment design}

The yellow loam [25] was collected from Huangyan District, Taizhou City, Zhejiang Province $\left(121^{\circ} 07^{\prime} 37 \mathrm{E}, 28^{\circ} 36^{\prime} 01^{\prime \prime} \mathrm{N}\right)$, mixed with chemical fertilizers (N:P:K 15:15:15; mixed mass ratio of fertilizer:soil was 0.003:1), and then dried in the air. The experiment was conducted in a green house by filling the pot with mixed soil and planting the 2-year-old satsuma mandarin (Citrus unshiu Marc.) trees. Holes were made at the bottom of the pot $\left(60^{*} 60 \mathrm{~cm}\right.$ of diameter and height) and covered with a 1-m-diameter plastic plate. Pots with mixed soil without any tree 
plantation were used as control (named $\mathrm{C}$ and set in four replicates). With no watering of mancozeb was set as treatment-0 (T0), watering twice with $2 \mathrm{~g}$ (ai.) of $80 \%$ mancozeb wettable powder 600 times diluted with water to soil as treat-2 (T2), watering 4 times with same concentration to soil as treat-4 (T4), watering 6 times with same concentration to soil as treat-6 (T6), and watering 8 times with same concentration to soil as treat-8 (T8). All treatments were performed in triplicate. The experiment started on May 4, 2018, the second watering on May 23, 2018, the third watering on June 8,2018 , the fourth watering on June 29,2018 , the fifth watering on July 27,2018 , the sixth watering on August 11, 2018, the seventh watering on September 5, 2018, and the eighth watering on September 23, 2018.

\subsection{Soil sampling}

All soil samples (500 g soil pot-1) were collected on October 11, 2018, about $25 \mathrm{~cm}$ underneath soil far inside $10 \mathrm{~cm}$ from the citrus canopy drip line in three directions $\left(120^{\circ}\right.$ as the boundary) from each tree was gathered and mixed as one sample, four samples were pooled together as one replication. After air drying, the samples were gently ground, sieved $(2 \mathrm{~mm})$ and put in the ice box and transported to the laboratory for subsequent analysis [26-28].

\subsection{Soil chemical property measurements}

The soil $\mathrm{pH}$ was determined in 1:2.5 (soil: water) soil water suspensions using a $\mathrm{pH}$ meter. The soil organic matter content was determined on the basis of oxidation with $\mathrm{K}_{2} \mathrm{Cr}_{2} \mathrm{O}_{7}$ in a heated oil bath. Hydrolysable $\mathrm{N}$ was determined by the alkaline hydrolysis diffusion method. Available $\mathrm{P}$ was extracted from the soil with $0.5 \mathrm{M} \mathrm{NaHCO}_{3}(\mathrm{pH} 8.5)$ and determined spectrophotometrically as blue molybdate-phosphate complex under partial reduction with ascorbic acid. Available $\mathrm{K}$ and exchangeable $\mathrm{Mg}, \mathrm{Ca}$, and $\mathrm{Mn}$ were extracted from the soil with $1 \mathrm{M}$ ammonium acetate $(\mathrm{pH}$ 7.0) and assayed using atomic absorption spectrophotometry $(\mathrm{Ca}, \mathrm{Mg}$, and $\mathrm{Mn}$ ) or flame spectrophotometry (K). Available $\mathrm{Cu}$ and $\mathrm{Zn}$ were extracted using solutions of diethylenetriaminepentaacetic acid (DTPA) at $\mathrm{pH} 7.3$ and determined using atomic absorption spectrophotometry [29-30].

\subsection{Soil microbial biomass measurement}

The soil microbial biomass $C$ was determined using the fumigation-extraction method followed by titration with an acid solution [31]. The $C$ content in the extract was determined by following the modified procedure of Snyder and Trofymow [32]. A portion of the soil sample (10 g) was fumigated using ethanol-free chloroform under reduced pressure followed by incubation at $25^{\circ} \mathrm{C}$ for $24 \mathrm{~h}$. The fumigated soil and another portion of the same soil sample (10 g, unfumigated) were separately extracted with $0.5 \mathrm{M} \mathrm{K}_{2} \mathrm{SO}_{4}$. The $\mathrm{C}$ content in the extract was determined by digesting an aliquot of the filtered extract with $\mathrm{K}$ persulfate/sulfuric acid. The evolved $\mathrm{CO}_{2}$ was trapped in a $\mathrm{NaOH}$ solution and quantified titrimetrically in the presence of $\mathrm{BaCl}_{2}$. The microbial biomass $\mathrm{C}$ was determined by calculating the difference in the $\mathrm{C}$ content of fumigated and unfumigated soil using a correction factor $(\mathrm{Kc})$ of 0.45 [33-34].

\subsection{Sequencing library construction}

DNA extraction and polymerase chain reaction (PCR) amplification microbial DNA was extracted from $0.5 \mathrm{~g}$ soil samples using the QIAampFast Soil DNA Stool Mini Kit (Qiagen, Germany) according to the manufacturer's protocols. The V3-V4 regions of the bacterial 16S rRNA gene were amplified using PCR $\left(94^{\circ} \mathrm{C}\right.$ for $3 \mathrm{~min}$, followed by 20 cycles at $94^{\circ} \mathrm{C}$ for $10 \mathrm{~s}, 55^{\circ} \mathrm{C}$ for $15 \mathrm{~s}, 72^{\circ} \mathrm{C}$ for $30 \mathrm{~s}$, and a final extension at $72^{\circ} \mathrm{C}$ for $7 \mathrm{~min}$ ), hold at $10^{\circ} \mathrm{C}$ using primers (336F:5'-GTACTCCTACGGGAGGCAGCA-3'; 806R:5'-GTGGACTACHVGGGTWTCTAAT-3'). PCR reactions were performed in triplicate in a $25-\mu \mathrm{L}$ mixture containing $2.5 \mu \mathrm{L}$ of $10 \times$ Ex Taq Buffer, 1 $\mu \mathrm{L}$ of $2.5 \mathrm{mM}$ dNTPs, $0.5 \mu \mathrm{L}$ of each primer $(5 \mu \mathrm{M}), 0.1 \mu \mathrm{L}$ of Takara Ex Taq, and $10 \mathrm{ng}$ template DNA. Two rounds of amplification were performed. Illumina MiSeq sequencing amplicons were extracted from $2 \%$ agarose gels and purified using the AxyPrep DNA Gel Extraction Kit (Axygen 
Biosciences, CA, USA) according to the manufacturer's protocols and quantified using QuantiFluor-ST (Promega Corporation, WI , USA). Purified amplicons were pooled in equimolar amounts and paired-end reads were sequenced $(2 \times 300)$ on an Illumina MiSeq platform (Genenergy Laboratories, Shanghai, China) according to the standard protocols.

\subsection{Statistical analyses}

The resultant data from each experiment were analyzed using SPSS version 20.0 software with advanced models (SPSS Japan Inc., Tokyo, Japan). The mean values of replicates were expressed as mean \pm standard error (SE). Means were compared for significant differences using the Duncan's test $(P \leq 0.05$ and $P \leq 0.01)$. The rarefaction analysis based on Mothur software (v.1.21.1) was conducted to reveal the diversity indices, including the Chao, ACE, and Shannon diversity indices[35]. The beta diversity analysis was performed with UniFrac to compare the results of the principal component analysis (PCA) using the R package prcomp and nonmetric multidimensional scaling (NMDS) using the R package meta MDS (Version 2.20) [36]. Venn diagrams were implemented using the Venn Diagram R package. Mantel test, redundancy analysis (RDA), and heatmap generation were performed in Vegan packages in unweighted pair group method with arithmetic (UPGMA) mean clustering using the $\mathrm{R}$ package hclust [37]. The coverage of the predicted diversity in each clone library was calculated using the formula $C=\left[1-\left(n_{1} / N\right)\right] \times 100 \%$, where $N$ is the total number of clones, and $n_{1}$ is number of operational taxonomic units (OTUs) appearing only once in the library [38].

\section{Results}

\subsection{Soil chemical properties}

The influence of mancozeb on soil chemical properties revealed that the $\mathrm{pH}$ value, soil organic matter content, available $\mathrm{P}, \mathrm{Fe}$, and exchanged $\mathrm{Mg}$ had no difference $(P<0.05)$ for all treatments. The content of hydrolysable $\mathrm{N}$, available $\mathrm{Mn}, \mathrm{Zn}$, and exchanged $\mathrm{Ca}$ increased with the increase in the watering mancozeb times, while the available $\mathrm{Cu}$ and $\mathrm{K}$ decreased accordingly. Compared with $\mathrm{T0}$, available $\mathrm{Mn}$ and $\mathrm{Zn}$ increased four and three times, respectively, in the T8 treatment (Table.1).

\subsection{Soil microbial biomass}

The soil microbial biomass was $1.09-1.14 \mathrm{~g} \mathrm{~kg}^{-1}$, with no significant difference $(P<0.05)$ in all treatments.

\subsection{Sequencing summary}

The two-terminal sequences and the base with a tail mass value less than 25 were removed simultaneously, $50 \mathrm{bp}$ sliding window and 1-bp genomic DNA walking were set, and the average base mass in the window was no less than 25. Finally, the sequences with a length of less than 100 bp were removed. The available sequences for the OTU analysis were 17,052-34,476. The number of OTUs was 214-721, and the mean length of the sequence was 448.23 after eliminating repetitive sequences, chimeric sequences, mitochondria, and contamination sequences. The rarefaction curve leveled off after the total number of sequences reached 15,000 in the sequencing process (Figure. $1 \mathrm{~A})$, indicating that the sequencing amount was more reasonable. The Shannon curve tended to flatten, indicating that the sequencing amount was sufficient to reflect the information of most species in the sample (Figure. 1B).

\subsection{Rhizosphere-associated bacterial richness and diversity}

Table 2 shows that the coverage of each sample was 0.9934-0.9997, indicating that the probability of species detected in the sample was very high. The Shannon index was $0.8352-0.8554$, indicating that the distribution of species in the sample was relatively uniform. The Shannon index under different times of mancozeb application after citrus planting was 5.547-5.597, with no significant difference. However, the Shannon index of the soil with citrus planting was significantly higher than that of the soil without citrus planting, it was similar to richness, Chao and ACE indices, 
indicating that the abundance of rhizosphere-associated bacterial communities increased significantly after planting citrus.

\subsection{Correlation of rhizosphere-associated bacterial communities in different samples}

The PCA plot of bacterial communities based on the relative abundance of phyla in control and treated soils showed variation in the profiles of the first component (PC1) (39.67\%) and the second component (PC2) (9.13\%)(Fig. 4). The rhizosphere-associated bacterial communities of the control soil without planting citrus (C-1 to C-4), soil without mancozeb application (T0-1 to T0-3), soil with mancozeb application twice (T2-1 to T2-3), soil with mancozeb application four times (T4-1 to T4-3), soil with mancozeb application six times (T6-1 to T6-3), and soil with mancozeb application eight times (T8-1 to T8-3) clustered in different quadrants, indicating that the rhizosphere-associated bacterial community structures of the soil differed substantially between without planting citrus and citrus growing. However, there were no significant difference in treated samples with citrus growing. Moreover, the PCA ordination clearly indicated the significant differences in bacterial communities between samples of the control with no citrus planting and other treated samples (Figure. 2A). The NMDS analysis showed that the result was the same as that of PCA (Figure. 2B). A significant difference in rhizosphere-associated bacterial communities was found between the sample with no citrus planting and the soil sample with citrus planting (Figure. 2C). A minor difference was observed between soil microorganisms after mancozeb application for different times in the Venn graph (Figure. 2D).

\subsection{Rhizosphere-associated bacterial community structure and abundance ratio}

Two hundred and ten rhizosphere-associated bacterial genera were identified, which were mainly affiliated with 20 phylums, including Proteobacteria, Acidobacteria, Chloroflexi, Bacteroidetes, Actinobacteria, Armatimonadetes, Candidatus Saccharibacteria, Chlamydiae, Cyanobacteria, Elusimicrobia, Firmicutes, Gemmatimonadetes, Nitrospirae, Parcubacteria, Planctomycetes, Spirochaetes, Unclassified_Bacteria, Verrucomicrobia, candidate division WPS-1, and candidate division WPS-2. The most dominant bacterial group was Proteobacteria $(31.28 \%-$ $44.65 \%)$, followed by Acidobacteria (16.32\%-37.28\%) and Actinobacteria (2.10\%-10.90\%). The proportion of other bacterial groups was relatively low.

The relative abundance of Acidobacteria increased after planting citrus, in addition, it decreased with the increase in mancozeb application. Similarly, the relative abundance of Armatimonadetes, Candidatus_Saccharibacteria, Gemmatimonadetes, Thermosporothrix, Planctomycetes, and Verrucomicrobia increased after planting citrus, although their relative abundance was lower than that of Elusimicrobia and Spirochaetes bacterial phyla in the soil after planting citrus. Conversely, the relative abundance of Proteobacteria, Actinobacteria, Bacteroidetes, Chlamydiae, and Firmicutes decreased after planting citrus. Further, the relative abundance of Candidatus Saccharibacteria, Parcubacteria, and Proteobacteria increased with multiple applications of mancozeb. Meanwhile, the abundance of Nitrospirae decreased with multiple applications of mancozeb. However, the abundance of Bacteroidete, candidate division WPS-1, and candidate division WPS-2 showed no significant changes (Figure. 3). At the genera level, the lowest diversity was observed in the sample with no citrus planting, it was 102 strains, soil without mancozeb application, 177 strains, soil with mancozeb application twice, 176 strains, soil with mancozeb application four times, 170 strains, soil with mancozeb application six times, 173 strains, and soil with mancozeb application eight times,180 strains. Meanwhile, the abundance of Genera Humibacter, Subdivision3_genera_incertae_sedis, Gp16 increased and the abundance of Genera Nitrospirae decreased after applications times of mancozeb (Figure. 4).

\section{Discussion}

Our result showed the abundance of rhizosphere-associated bacterial species increased significantly and changed in rhizosphere bacterial community composition in response to citrus 
planting, plants root exudates have important effects on the abundance, diversity, and activity of soil microorganisms supporting the findings of this study [39].

Citrus is an important perennial fruit tree in the world. Citrus rhizosphere microbiome are the microorganism closely attached to the rhizosphere, which plays an important role in promoting citrus growth and development. Xu et al. suggested that plant-microbe interactions are very likely to be important factors that influence the assembly of rhizosphere microbiomes, such as bacterial secretion systems [40]. The enrichment of rhizosphere microbes can be attributed to their lifestyles [41-42]. Delgado-Baquerizo et al. reported that only $2 \%$ of bacterial taxa made up nearly half of the soil bacteria at various sites around the world [43]. Meanwhile, $\mathrm{Xu}$ et al. also found that there are only a few bacterial taxa, such as Proteobacteria, Actinobacteria, Acidobacteria, and Bacteroidetes, which are abundant in the citrus rhizosphere [40]. Similarly, we found that the dominant bacterial groups were Proteobacteria, Acidobacteria, and Actinobacteria in the citrus-cultivated rhizosphere soil, while the other bacterial groups were non-dominant bacteria.

You et al. showed the relative abundance of sequences affiliated with Proteobacteria, Gemmatimonadetes and Nitrospirae were increased after treatment with fungicide metalaxylmancozeb [19], but the relative abundance of sequences affiliated with Acidobacteria, Planctomycetes, Chloroflexi and Firmicutes were reduced. Moreover, fungicide treatment caused the disappearance of sequences affiliated with Bacteroidetes and appearance of sequences affiliated with Verrucomicrobia. In our study, the data indicated that the relative abundance of major phyla slightly differed between different times of mancozeb application, the multiple application of mancozeb significantly improved the relative abundance of Candidatus Saccharibacteria, Parcubacteria, and Proteobacteria, but reduced the relative abundance of Nitrospirae. The relative abundance variation of Proteobacteria is same as their result, the other rhizosphere-associated bacterial species relative abundance variation differed from their result likely due to the different fungicide. Mancozeb is generally unstable in the presence of moisture or oxygen and in biological systems, the degradation products such as ethylene thiourea, ethylene urea are suitable substrates for some microorganisms [44-45], thereby, the relative abundance of Candidatus Saccharibacteria, Parcubacteria, and Proteobacteria increased with multiple applications of mancozeb in present study.

Walia et al. found that the population of Actinomycetes generally decreased when mancozeb was sprayed to the soil without growing any plant [24]. In additon, 1000 and $2000 \mathrm{mg} \mathrm{kg}^{-1}$ of mancozeb had adverse effects on the population of Actinomycetes. The more mancozeb was sprayed, the less of Actinomycetes population was. After 4 weeks of incubation, the bacterial population on an average returned the original level. Meanwhile, at different concentrations incubating for 20 days, the decrease of microbial biomass $C$ of soil samples at concentrations of 0 and $10 \mathrm{mg} \mathrm{kg}^{-1}$ and the increase in the microbial biomass $C$ at concentrations of 100, 250, and $500 \mathrm{mg}$ $\mathrm{kg}^{-1}$ were not statistically significant [22]. In the present study, mancozeb was sprayed at $1333 \mathrm{mg}$ $\mathrm{kg}^{-1}$ (600 times) concentration in the citrus planting pot, the relative abundance of Actinomycetes in all treatmentshad no significant change. Meanwhile, there was no significant difference in the microbial biomass $C$ in different treatment of mancozeb application, the last watering date of this study was September 23, 2018, and the soil sampling time was on October 11, 2018, and the present study lasted 1 year, the soil sample was detected after 20 days, which did not reflect a complete response to the potential risk of using mancozeb on soil microorganisms, possibly the adverse effect is not lasting. However, the potential risk of using mancozeb on soil microorganisms may still exist but likely happen in dose dependent manner, previous studies have shown that mancozeb has toxic effects on soil ammonification, nitrification and denitrification. It is a strong inhibitor of soil nitrification [46], the population of nitrifying bacteria in the soil treated with fungicides mancozeb drastically reduced with the application of $1500 \mathrm{mg} \mathrm{kg}^{-1}$ of the soil and an exposure time of 28 days. A similar but comparatively less pronounced effect was observed for insecticide diazinon and 
herbicide linuron [22,47]. Kinney et al. observed the toxic effects of mancozeb, chlorothalonil, and prosulfuron (fungicides and herbicides) on nitrification and denitrification during an incubation period of $48 \mathrm{~h}$, nitrification and denitrification produced nitrous oxide $\left(\mathrm{N}_{2} \mathrm{O}\right)$ and nitric oxide $(\mathrm{NO})$, which are environmentally significant trace gases produced in soil by the processes of nitrification and denitrification [48]. The present study showed that the Nitrospirae decreased after applications times of mancozeb, the residue of hydrolysable $\mathrm{N}$ in the soil increased with mancozeb application times especially in $\mathrm{T} 8$ treatment, probably because mancozeb significantly inhibited Nitrospirae thus led to decreased release of nitrogen in the acid soil.

Genera Subdivision3_genera_incertae_sedis is affiliated to the phylum Verrucomicrobia, which was negatively correlated with soil fertility [49-50], hence, the abundance of Subdivision3_genera _incertae_sedis genus increased with multiple applications of mancozeb possibly resulted the soil fertility decreasing. The Genera Gp16 was found to be highly positively correlated with plant growth. No evidence relating Gp16 to plant disease or disease suppression exists in the literature [51], in present study, with multiple applications of mancozeb, the input of mancozeb may promote the Gp16 growth, we speculated besides the mancozeb degradation products increased the abundance of Gp16, the Mn and Zn element as micronutrients fertilizer has the advantages of stimulating plants root exudates. Members of Genera Burkholderia and Bradyrhizobium have been known to benefit plants, because Burkholderia is one of the most abundant bacteria associated with citrus roots, and Burkholderia showed the best antagonistic activities against Sinorhizobium meliloti, a relative of the HLB causal agent Las, and several other citrus pathogens, such as Phytophthora spp. and Alternaria alternate, the majority of the Bradyrhizobium were associated with cell wall synthesis [1], we found the abundance of Burkholderia and Bradyrhizobium improved slightly with multiple applications of mancozeb.

Chaudhry et al. reported a negative effect of zinc on the copper uptake by rice plants. As copper and zinc have two plasma membrane transporters in common (P1B-Zn-ATPases) [52], these findings suggested that the competition at the common plasma membrane transporters might be relevant in the case of an antagonist. In the present study, the available $\mathrm{Zn}$ increased in the soil with the increase in the watering frequency of mancozeb. Also, the $\mathrm{Cu}$ uptake increased on account of the available $\mathrm{Zn}$ sufficiency, and therefore the available $\mathrm{Cu}$ in the soil decreased accordingly.

It is also worth noting that the rhizosphere-associated bacterial community structures of the soil were no significant difference in treated samples for without mancozeb application (T0-1 to T0-3), soil with mancozeb application twice (T2-1 to T2-3), soil with mancozeb application four times (T4-1 to T4-3), soil with mancozeb application six times (T6-1 to T6-3), and soil with mancozeb application eight times (T8-1 to T8-3) in our correlation analysis, it suggested that mancozeb sustainably application maybe had little effect. However, long-term use of mancozeb may pose a risk of environmental damage to the orchard soil caused by excessive Mn [22,53].

\section{Conclusions}

Overall, this study showed that the abundance of rhizosphere-associated bacterial species increased significantly after citrus planting. With the repeated application of mancozeb, the less adverse effects of mancozeb on the citrus-cultivated rhizosphere soil were observed. The relative abundance of Candidatus Saccharibacteria, Parcubacteria, and Proteobacteria increased with multiple applications of mancozeb. Meanwhile, the abundance of Nitrospirae decreased with multiple applications of mancozeb. Further investigation on of mancozeb on the citrus rhizosphere bacterial community is needed to evaluate for consecutive year application.

Author contributions: Conceived, designed the experiments, writing-original draft preparation, writing-review and editing, Z.D.H.; Investigation, performed the experiments, sampling, P.W., Z.X P., L.M. L., G.Q. C., X.R. H., Y.P. Gand Z.D.H.; Analyzed the data, Z.D. H. ,P.W. and A.F.; All authors have read and 
approved the manuscript.

Funding: This study was supported by the Ministry of Science and Technology of the People Republic of China, Project no. 2017YFD0202000. Key R \& D projects in Zhejiang, Project no.2019C02022.

Acknowledgments: We acknowledge Dr. Irfansohail for helpful scientific discussion.

Conflicts of interest: The authors report no conflicts of interest related to this study.

\section{References:}

1. Zhang, Y.; Xu, J.; Riera, N.; Jin, T.; Li, J.Y.; Wang, N. Huanglongbing impairs the rhizosphere-to-rhizoplane enrichment process of the citrus root-associated microbiome. Microbiome 2017,5,97, doi: 10.1186/s40168-017-0304-4.

2. Mendes, R.; Kruijt, M.; Bruijn, I.D.; Dekkers, E.; Voort, M. V. D.; Schneider, J.H.M.; Piceno,Y.E.; DeSantis,T.Z.; Andersen;G.L.; Bakker,P.A.H.M.; Raaijmakers,J.M. Deciphering the rhizosphere microbiome for disease suppressive bacteria. Science 2011,332, 1097-1100, doi:10.1126/science.1203980.

3. Busby, P. E.; Soman, C.; Wagner, M.R.; Friesen, M.L.; Kremer, J.; Bennett, A.; Morsy, M.; Eisen, J.A.; Leach, J.E.; Dangl, J.L. Research priorities for harnessing plant microbiomes in sustainable agriculture. PLoS Biol. 2017,15, e2001793, doi:10.1371/journal.pbio.2001793

4. Prashar, P.; Shah, S. Impact of fertilizers and pesticides on soil microflora in agriculture. In: Lichtfouse, E. (Ed.), Sustainable Agriculture Reviews, 19. Springer International Publishing, Switzerland, 2016, 331-361, doi:10.1007/978-3-319-26777-7_8.

5. Jhade, R.K.; Huchche, A.D.; Dwivedi, S.K. Phenology of flowering in citrus: Nagpur mandarin (Citrus reticulata Blanco) perspective. International Journal of Computer Systems. 2018, 6, 1511-1517, ISSN: 2349-8528.

6. Wang, N.; Pirson, E.A.; Setubal, C.; Xu, J.; Levy, J.G.; Zhang, Y.Z.; Li, J.Y.; Rangel, L.Z.; Martins J. Jr. The Candidatus Liberibacter-host interface: insights into pathogenesis mechanisms and disease control. Annu. Rev. Phytopathol. 2017,55,451-482, doi:10.1146/annurev-phyto-080516-035513.

7. Shuqin, J.; Fang, Z. Zero growth of chemical fertilizer and pesticide use: China's objectives, progress and challenges. Journal of resources and ecology 2018, 9, 50-58, doi:10.5814/j.issn.1674-764x.2018.01.006.

8. Yadav M, Shukla A.K, Srivastva N, Upadhyay S.N, Dubey S.K. Utilization of microbial community potential for removal of chlorpyrifos:a review. Crit Rev Biotechnol 2016, 36, 727-742, doi:10.3109/07388551.2015.1015958.

9. Wang, Y.S., Huang, Y.J., Chen, W.C., Yen, J.H. Effect of carbendazim and pencycuron on soil bacterial community. Journal of Hazardous Materials 2009,172, 84-91, doi:10.1016/j.jhazmat.2009.06.142.

10. Baćmaga,M., Kucharski, J.,Wyszkowska, J. Microbial and enzymatic activity of soil contaminated with azoxystrobin. Environmental Monitoring and Assessment 2015,187, 615-630, doi:10.1007/s10661-015-4827-5.

11. Ezirim, C.Y., Chikezie, P.C., Theanacho, K.M., Nwachukwu, N.R. Comparative activities of soil enzymes from polluted sites in Egbema, Imo State, Nigeria. Journal of Pollution Effects and Control 2017,5, 185-192, doi: 10.4172/2375-4397.1000185.

12. Aktar, M.W.; Sengupta, D.; Chowdhury, A. Impact of pesticides use in agriculture: their benefits and hazards. Interdisciplinary toxicology 2009, 2, 1-12, doi:10.2478/v10102-009-0001-7.

13. Popp, J.; Petö, K.; Nagy, J. Pesticide productivity and food security. A review. Agronomy for Sustainable Development 2013, 33, 243-255, doi:10.1007/s13593-012-0105-x.

14. Mondal, S.N.; Vicent, A.; Reis, R.F.; Timmer, L.W. Efficacy of preand post inoculation application of fungicides to expanding young citrus leaves for control of melanose, scab, and Alternaria brown spot. Plant Disease 2007, 91, 1600-1606.

15. FAOSTAT, Rome, Italy. Online at http://faostat.fao.org/site/339/default.aspx. 2010. 
16. Chen, G.Q.; Jiang, L.Y.; Xu, F.S.; Li H.Y. In vitro and in vivo screening of fungicides for controlling citrus melanose caused by Diaporthe citri. Journal of Zhejiang University 2010, 36, 440-444, doi:10 .3785/j .issn .1008-9209.2010.04 .014.

17. Jiang, L.Y.; Xu, F.S.; Huang Z. D.; Huang, F.; Chen, G.Q.; Li, H.Y. Occurrence and control of citrus melanose caused by Diaporthe citri. Acta Agriculturae Zhejiangensis 2012, 24, 647-653, doi:10.3969/j.issn.1004-1524.2012.04.022.

18. Gopal, K.; Lakshmi, M.L.; Sarada, G.; Nagalakshmi, T.; Sankar, G.T.; Gopi, V.; Ramana, K.T.V. Citrus melanose (Diaporthe citri Wolf): A review. International Journal of Current Microbiology and Applied Sciences 2014, 3, 113-124, ISSN: 2319-7706.

19. You, C.; Zhang, C.; Kong, F.; Feng, C.;Wang J. Comparison of the effects of biocontrol agent Bacillus subtilis and fungicide metalaxyl-mancozeb on bacterial communities in tobacco rhizospheric soil. Ecological engineering 2016, 91,119-125, doi:10.1016/j.ecoleng.2016.02.011.

20. Wang, X.; Song, M.; Wang, Y.; Gao, C.; Zhang, Q.; Chu, X.; Fang, H.; Yu, Y. Response of soil bacterial community to repeated applications of carbendazim. Ecotoxicology and Environmental Safety 2012, 75, 33-39, doi.org/10.1016/j.ecoenv.2011.08.014.

21. Sang, M.K.; Kim, K.D. Plant growth-promoting rhizo-bacteria suppressive to Phytophthora blight affect microbial activities and communities in the rhizosphere of pepper (Capsicum annuum L.) in the field. Applied Soil Ecology 2012, 62, 88-97, doi:10.1016/j.apsoil.2012.08.001.

22. Černohlávková, J.; Jarkovský, J.; Hofman, J. Effects of fungicides mancozeb and dinocap on carbon and N mineralization in soils. Ecotoxicology and Environmental Safety 2009, 72, 80-85, doi.org/10.1016/j.ecoenv.2008.07.001.

23. Cycoń, M.; Piotrowska-Seget, Z.; Kozdrój, J. Responses of indigenous microorganisms to a fungicidal mixture of mancozeb and dimethomorph added to sandy soils. International biodeterioration $\mathcal{E}$ biodegradation 2010, 64, 316-323, doi:10.1016/j.ibiod.2010.03.006.

24. Walia,A.; Mehta, P.; Guleria, S.; Chauhan, A.; Shirkot, C. K. Impact of fungicide mancozeb at different application rates on soil microbial populations, soil biological processes, and enzyme activities in soil. The Scientific World Journal 2014, 2-9, doi:10.1155/2014/702909.

25. Soil Survey Staff. 12th ed USDA-Natural Resources Conservation Service, Washington, DC. 2014

26. Lu, R.K. Methods of Soil and Agrochemistry Analysis. China Agriculture Science E Technology Press, Beijing, China 2000, ISBN 7-109-06644-4.

27. Gil, P.M.; Bonomelli, C.; Schaffer, B.; Ferreyra, R.; Gentina, C. Effect of soil water-to-air ratio on biomass and mineral nutrition of avocado trees. Journal of Soil Science and Plant Nutrition 2012,12, 609-630, doi:10.4067/S0718-95162012005000020.

28. Li, Y.; Han, M. Q.; Lin, F.;Ten, Y.; Lin, J.; Zhu, D. H.; Guo, P.; Weng, Y.B.; Chen, L. S. Soil chemical properties,'Guanximiyou'pummelo leaf mineral nutrient status and fruit quality in the southern region of Fujian province, China. Journal of Soil Science and Plant Nutrition 2015, 15, 615-628, doi:10.4067/S0718-95162015005000029.

29. Kowalenko, C.G.; Lavkulich, L.M. A modified curcumin method for boron analysis of soil extracts. Canadian Journal of Soil Science 1976, 56, 537-539, doi:10.4141/cjss76-068.

30. Chen, A.H.; Jiao, B.N.; Wang, C.Q. Extraction of mineral elements from citrus leaves with boiling hydrochloric acid. Journal of Fruit Science 2011, 28, 1107-1110, doi:10.13925/j.cnki.gsxb.2011.06.038.

31. Jenkinson, D.S.; Powlson, D.S. The effects of biocidal treatments on metabolism in soil-I. Fumigation with chloroform. Soil Biology and Biochemistry 1976, 8, 167-177, doi: 10.1016/0038-0717(76)90001-8. 
32. Snyder, D.; Trofymow, J.A. Rapid accurate wet oxidation diffusion procedure for determining organic and inorganic carbon in plant and soil samples. Communications in Soil Science and Plant Analysis 1984,

15,1587-1597, doi:10.1080/00103628409367499.

33. Sharma, K.L.; Chandrika, D.S.; Grace, J.; Srinivas, K.; Mandal, U.K.; Raju, B.M.K.; Kumar, T.S.; Rao, C.S.; Reddy, K.S.; Osman, M.; Indoria, A.K. Long-term effects of soil and nutrient management practices on soil properties and additive soil quality indices in satalfisols. Indian journal of dry land agricultural research and development 2014, 29,56-65, doi:10.5958/2231-6701.2014.01216.0.

34. Debnath, S.; Patra, A.K.; Ahmed, N.; Kumar, S.; Dwivedi, B.S. Assessment of microbial biomass and enzyme activities in soil under temperate fruit crops in north western himalayan region. Journal of Soil Science and Plant Nutrition 2015, 15, 848-866, doi:10.4067/S0718-95162015005000059.

35. Schloss, P. D.; Westcott, S. L.; Ryabin, T.; Hall, J.R.; Hartmann, M.; Hollister, E.B.; Lesniewski, R.A.; Oakley, B.B.; Parks, D.H.; Robinson, C.J.; Sahl, J. W.; Stres, B.; Thallinger, G.G.V.; Horn, D.J.; Weber, C.F. Introducing mothur: open-source, platform-independent, community-supported software for describing and comparing microbial communities. Applied and Environmental Microbiology 2009, 75, 7537-7541, doi:10.1128/AEM.01541-09.

36. Oksanen, J.; Blanchet, F.G.; Kindt, R.; Legendre, P.; O'Hara, R.B.; Simpson,G.L.; Solymos, P.; Stevens, M.H.H.; Wagner, H. Vegan: community ecology package. R package version 1.17-4. online at http://cran. r-project. org >. Acesso em. 23, 2010.

37. R Core Team, R: A Language and Environment for Statistical Computing. R Foundation for Statistical Computing, Vienna Austria (URL http://www.R- project.org/) 2015, doi:10.1890/0012-9658(2002)083[3097:CFHIWS]2.0.CO;2.

38. Good, I.J. The population frequencies of species and the estimation of the population parameters. Biometrika 1953, 40, 237-264, doi:10.1093/biomet/40.3-4.237.

39. Berg, G; Smalla, K. Plant species and soil type cooperatively shape the structure and function of microbial communities in the rhizosphere. FEMS microbiology ecology 2009, 68(1): 1-13, doi:10.1111/j.1574-6941.2009.00654.x.

40. Xu, J.;Zhang, Y.Z.; Zhang, P.F.; Trivedi, P.; Riera, N.; Wang, Y.Y.;Liu, X.; Fan, G.Y.; Tang, J.L.; Coletta-Filho, H. D.; Cubero, J.; Deng, X.L.; Ancona, V.; Lu, Z.J.; Zhong, B.; Roper, M. C.; Capote, N.; Catara, V.; Pietersen, G.; Vernière, C.; Al-Sadi, A. M.; Li, L.; Yang, F.; Xu, X.; Wang, J.; Yang, H.; Jin, T.; Wang, N. The structure and function of the global citrus rhizosphere microbiome. Nature communications 2018, 9, 4894-4904, doi: 10.1038/s41467-018-07343-2.

41. Leff, J. W.; Jones, S.E.; Prober, S.M.; Barberán, A.; Borer, E.T.; Firn, J.L.; Harpole, W. S.; Hobbie, S. E.; Hofmockel, K.S.; Knops, J.M.H.; $\quad$ McCulley, R.L.; Pierre, K.L.; Risch, A.C.; Seabloom, E.W.; Steenbock, M.S.C.; Stevens, C.J.; Fierer, N. Consistent responses of soil microbial communities to elevated nutrient inputs in grasslands across the globe. proceedings of the national academy of sciences of the united states of America 2015, 112, 10967-10972, doi:10.1073/pnas.1508382112.

42. Trivedi, P.; Anderson, I. C.; Singh, B. K. Microbial modulators of soil carbon storage: integrating genomic and metabolic knowledge for global prediction. Trends in Microbiology 2013, 21, 641-651, doi:10.1016/j.tim.2013.09.005.

43. Delgado-Baquerizo, M.; Oliverio, A.M.; Brewer, T. E.; Benavent-González, A.; Eldridge, D.J.; Bardgett, R.D.; Maestre, F.T.; Singh, B. K.; Fierer1, N. A global atlas of the dominant bacteria found in soil. Science 2018, 359, 320-325, doi: 10.1126/science.aap9516.

44. Van L. H.; Schwack, W. Selective trace determination of dithiocarbamate fungicides in fruits and vegetables 
by reversed-phase ion-pair liquid chromatography with ultraviolet and electrochemical detection. Journal of Aoac International 2000, 83, 720-727, doi:10.1093/jaoac/83.3.720.

45. Vryzas, Z.; Papadakis, E.N.; Papadopoulou-Mourkidou, E. Microwave-assisted extraction (MAE)-acid hydrolysis of dithiocarbamates for trace analysis in tobacco and peaches. Journal of agricultural and food chemistry 2002, 50, 2220-2226, doi:10.1021/jf0111864.

46. Vonk, J.W. Testing of pesticides for side-effects on $\mathrm{N}$ conversions in soil. Toxicological and Environmental Chemistry 1991, 30, 241-248, doi:10.1080/02772249109357662.

47. Cycoń, M.; Piotrowska-Seget, Z. Effect of selected pesticides on soil microflora involved in organic matter and N transformations: pot experiment. Polish journal of ecology 2007, 55, 207-220, online at https://www.researchgate.net/publication/202249661.

48. Kinney, C.A.; Mandernack, K.W.; Mosier, A.R. Laboratory investigations into the effects of the pesticides mancozeb, chlorothalonil, and prosulfuron on nitrous oxide and nitric oxide production in fertilized soil. Soil Biology and Biochemistry 2005, 37, 837-850, doi:10.1016/j.soilbio.2004.07.044.

49. Huang, W. R.; Bai, Z. H.; Hoefel, D.; Hu, Q.; Lv, X.; Zhuang, G. Q. Effects of cotton straw amendment on soil fertility and microbial communities. Front. Environ. Sci. Eng. 2012, 6, 336-349, doi:10.1007/s11783-011-0337-z.

50. Navarrete, A. A.; Soares, T.; Rossetto, R.; Van V.J.A.; Tsai, S.M.; Kuramae, E.E. Verrucomicrobial community structure and abundance as indicators for changes in chemical factors linked to soil fertility. Antonie Van Leeuwenhoek 2015, 108, 741-752, doi:10.1007/s10482-015-0530-3.

51. Yin C; Hulbert S.H; Schroeder K.L; Mavrodi O; Mavrodi D; Dhingra A; Schillinger W.F; Paulitz T.C. Role of bacterial communities in the natural suppression of Rhizoctonia solani bare patch disease of wheat (Triticum aestivum L.). Appl Environ Microbiol .2013, 79,7428-7438, doi:10.1128/aem.01610-13.

52. Chaudhry, F. M.; Sharif, M.; Latif, A.; Qureshi. R. H. Zinc-Cu antagonism in nutrition of rice (oryzasatival). Plant and Soil 1973, 38, 573-80, doi:10.1007/BF00010697.

53. Hwang, E.S.; Cash, J.N.; Zabik, M.J. Determination of degradation products and pathways of mancozeb and ethylenethiourea (ETU) in solutions due to ozone and chlorine dioxide treatments. Journal of agricultural and food chemistry 2003, 51, 1341-1346, doi:10.1021/jf020764t. 
1

Table 1. Soil properties of citrus rhizosphere under different times of mancozeb application

\begin{tabular}{|c|c|c|c|c|c|}
\hline Soil property & T0 & $\mathrm{T} 2$ & $\mathrm{~T} 4$ & T6 & $\mathrm{T} 8$ \\
\hline $\mathrm{pH}$ & $4.90 \pm 0.07$ & $4.95 \pm 0.11$ & $4.84 \pm 0.07$ & $4.83 \pm 0.08$ & $4.81 \pm 0.03$ \\
\hline $\mathrm{SOM}(\mathrm{g} / \mathrm{kg})$ & $37.70 \pm 2.17$ & $39.17 \pm 1.52$ & $39.93 \pm 0.92$ & $38.63 \pm 0.08$ & $37.30 \pm 1.06$ \\
\hline $\mathrm{HN}$ (mg/kg) & $171.67 \pm 9.36 c$ & $192.63 \pm 12.99 b c$ & $204.80 \pm 7.24 \mathrm{ab}$ & $224.83 \pm 5.34 a$ & $229.20 \pm 15.81 a$ \\
\hline $\mathrm{AvP}(\mathrm{mg} / \mathrm{kg})$ & $543.33 \pm 14.14$ & $560.00 \pm 14.14$ & $516.67 \pm 10.80$ & $523.33 \pm 8.17$ & $546.67 \pm 10.80$ \\
\hline $\operatorname{AvK}(\mathrm{mg} / \mathrm{kg})$ & $221.00 \pm 23.06 \mathrm{ab}$ & $241.33 \pm 4.32 \mathrm{a}$ & $226.67 \pm 8.29 \mathrm{ab}$ & $197.00 \pm 15.99^{b}$ & $194.67 \pm 23.34^{b}$ \\
\hline AvFe $(\mathrm{mg} / \mathrm{kg})$ & $102.00 \pm 4.20$ & $100.97 \pm 4.35$ & $99.77 \pm 3.79$ & $103.23 \pm 4.83$ & $105.43 \pm 4.99$ \\
\hline AvMn（mg/kg） & $38.30 \pm 14.91 \mathrm{~d}$ & $57.60 \pm 2.74 c$ & $68.07 \pm 3.12 \mathrm{c}$ & $124.00 \pm 6.48 b$ & $178.30 \pm 7.95 a$ \\
\hline $\mathrm{AvCu} \quad(\mathrm{mg} / \mathrm{kg})$ & $3.06 \pm 0.05 a$ & $2.97 \pm 0.10 \mathrm{a}$ & $2.83 \pm 0.05 a$ & $2.55 \pm 0.10 \mathrm{~b}$ & $2.21 \pm 0.11 c$ \\
\hline AvZn (mg/kg) & $13.90 \pm 2.18 \mathrm{c}$ & $21.00 \pm 0.60 b$ & $21.97 \pm 1.60 \mathrm{~b}$ & $32.60 \pm 2.86 a$ & $37.37 \pm 2.69 a$ \\
\hline $\mathrm{ExCa}(\mathrm{cmol} / \mathrm{kg})$ & $2.20 \pm 0.16 b$ & $2.50 \pm 0.07 \mathrm{ab}$ & $2.80 \pm 0.21 \mathrm{a}$ & $2.73 \pm 0.16 a$ & $2.60 \pm 0.04 a$ \\
\hline ExMg $(\mathrm{cmol} / \mathrm{kg})$ & $0.47 \pm 0.00$ & $0.53 \pm 0.04$ & $0.53 \pm 0.04$ & $0.50 \pm 0.00$ & $0.50 \pm 0.00$ \\
\hline
\end{tabular}

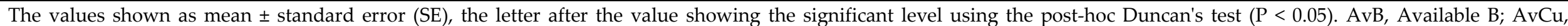

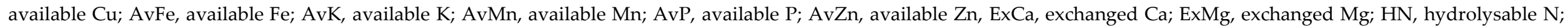
SOM, soil organic matter content.

6 Table 2. Bacterial Alpha diversity index with the $97 \%$ sequence similarity of the soil under different times of mancozeb application.

\begin{tabular}{|c|c|c|c|c|c|c|}
\hline$\alpha$-Diversity & T0 & $\mathrm{T} 2$ & $\mathrm{~T} 4$ & T6 & $\mathrm{T} 8$ & $\mathrm{C}$ \\
\hline Richness & $721.00 \pm 16.54 b$ & $718.67 \pm 8.20 b$ & $708.67 \pm 9.91 b$ & $694.00 \pm 26.17 \mathrm{~b}$ & $708.00 \pm 26.87 \mathrm{~b}$ & $214.50 \pm 0.41 \mathrm{a}$ \\
\hline Shannon & $5.55 \pm 0.085 b$ & $5.63 \pm 0.02 b$ & $5.56 \pm 0.06 b$ & $5.54 \pm 0.10 b$ & $5.60 \pm 0.02 b$ & $4.48 \pm 0.02 \mathrm{a}$ \\
\hline Chao & $771.07 \pm 31.69 b$ & $761.84 \pm 3.83 b$ & $770.13 \pm 15.27 b$ & $744.81 \pm 21.79 b$ & $760.08 \pm 24.20 b$ & $215.71 \pm 0.80 \mathrm{a}$ \\
\hline $\mathrm{ACE}$ & $756.89 \pm 23.72 b$ & $754.74 \pm 1.58 b$ & $761.52 \pm 13.44 b$ & $735.58 \pm 23.31 b$ & $745.46 \pm 21.79 b$ & $215.93 \pm 0.61 a$ \\
\hline Coverage & $0.9959( \pm 0.0006)$ & $0.9957( \pm 0.0013)$ & $0.9934( \pm 0.0014)$ & $0.9944 （ \pm 0.0008)$ & $0.9949( \pm 0.0016)$ & $0.9997( \pm 0.0001)$ \\
\hline shannoneven & $0.8430( \pm 0.0105)$ & $0.8554( \pm 0.0023)$ & $0.8475( \pm 0.0082)$ & $0.8476( \pm 0.0120)$ & $0.8531( \pm 0.0074)$ & $0.8352( \pm 0.0031)$ \\
\hline
\end{tabular}

7 The values shown as mean \pm standard error $(\mathrm{SE})$, the letter after the value showing the significant level using the post-hoc Duncan's test $(P<0.01)$. 
9

A

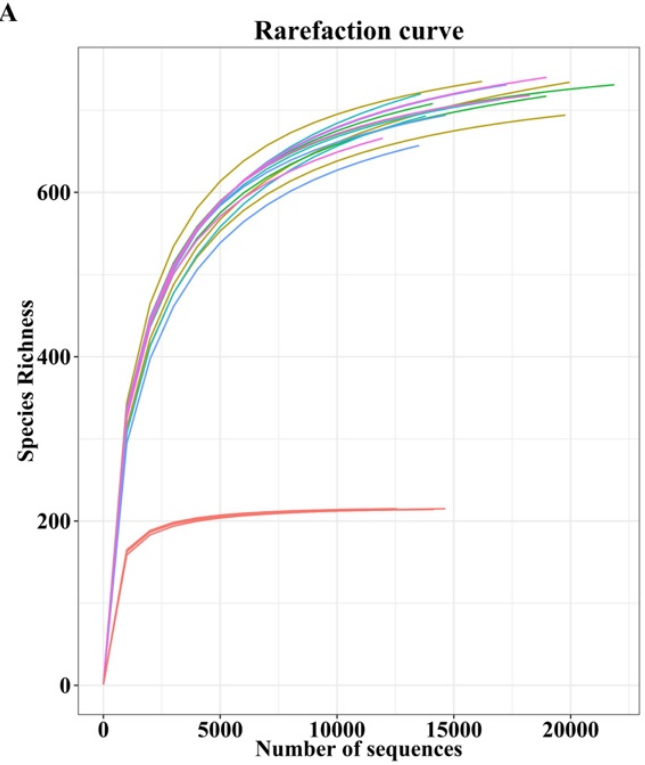

B

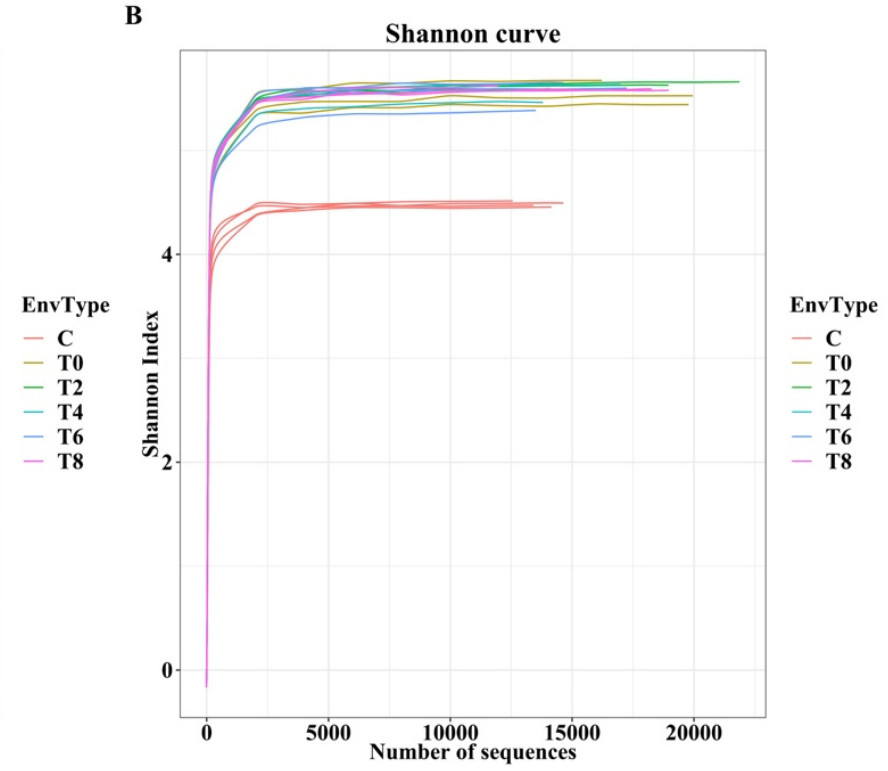

Figure 1. Rarefaction (A) and Shannon (B) curves of each sample at the 3\% cutoff level. 

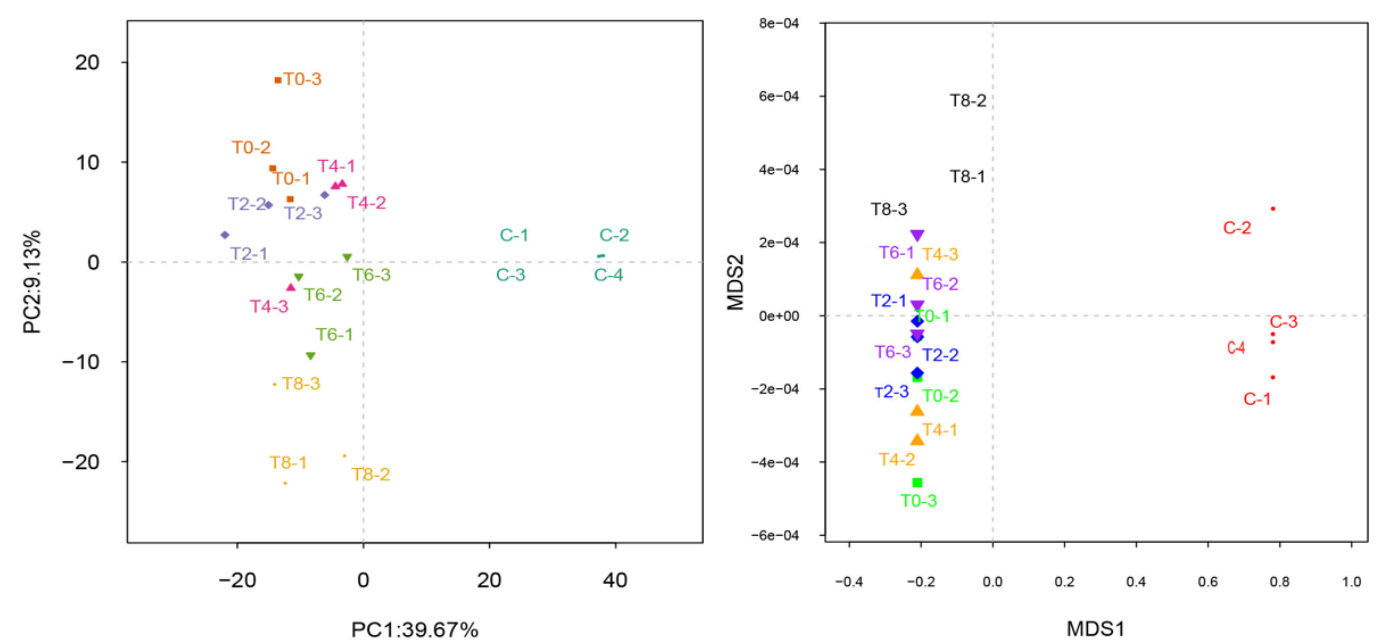

12

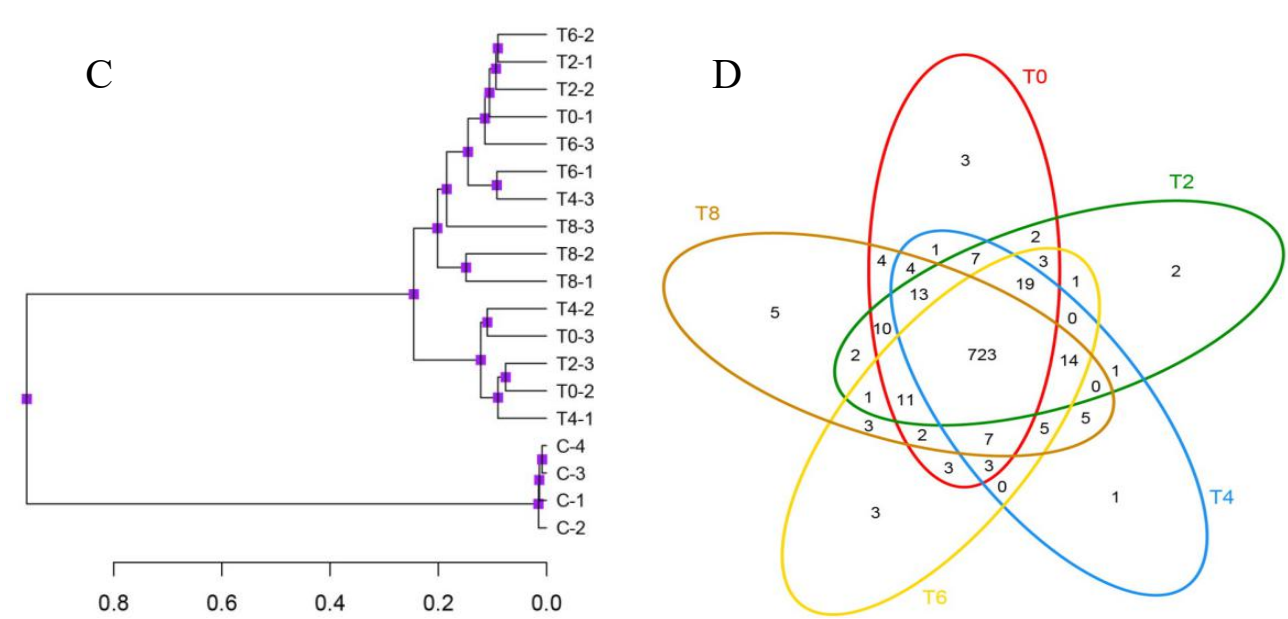

13

Figure 2. Principal component analysis (A) and nonmetric multidimensional scaling (B) of rhizosphere

15 bacterialcommunity in the citrus rhizospheric soil under different times of mancozeb application, Cluster tree

16 (C) and venn graph (D) of different citrus rhizospheric soil samples. 


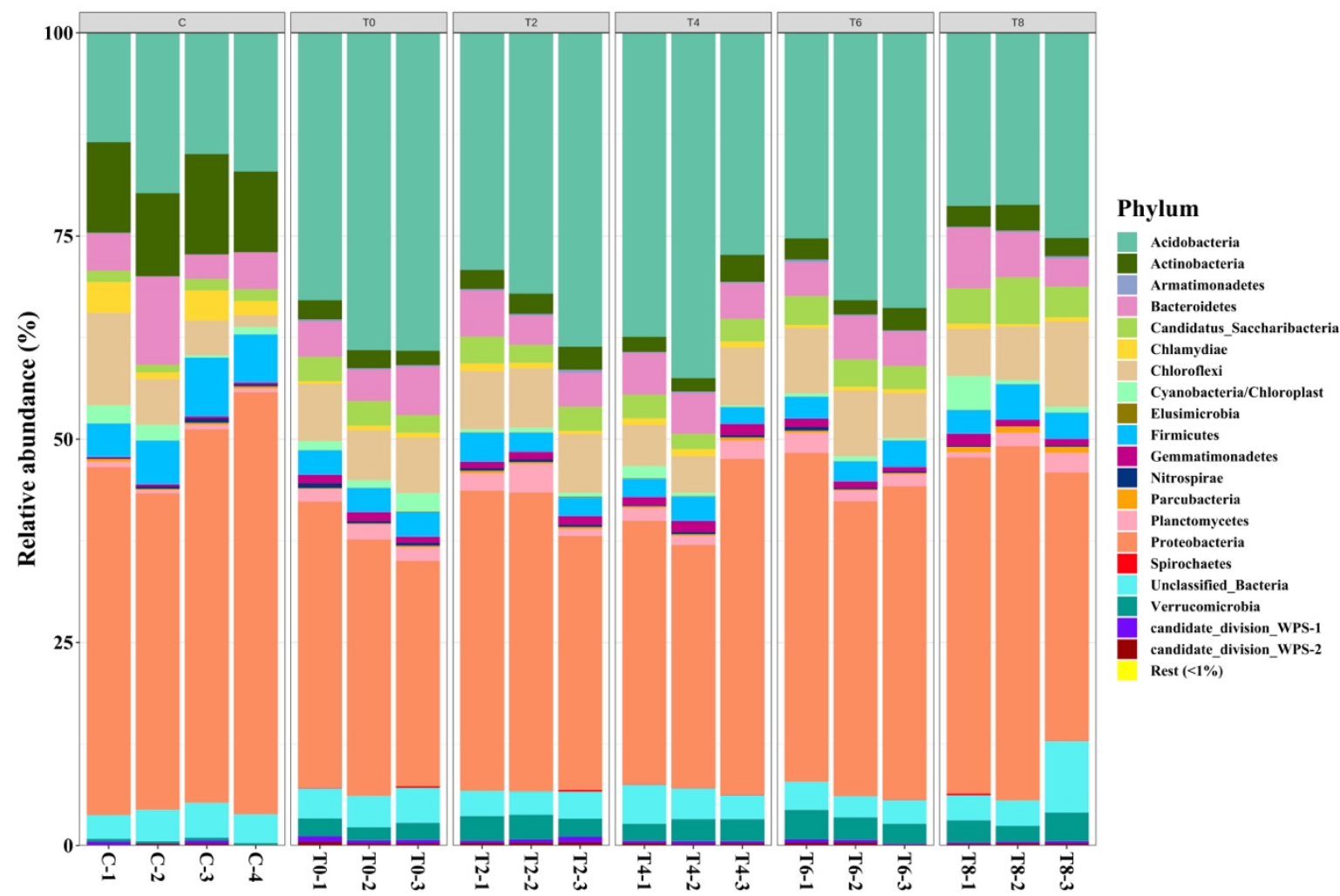

Figure 3. Relative abundance of bacterial phyla in the citrus rhizospheric soil under different times of mancozeb application. 

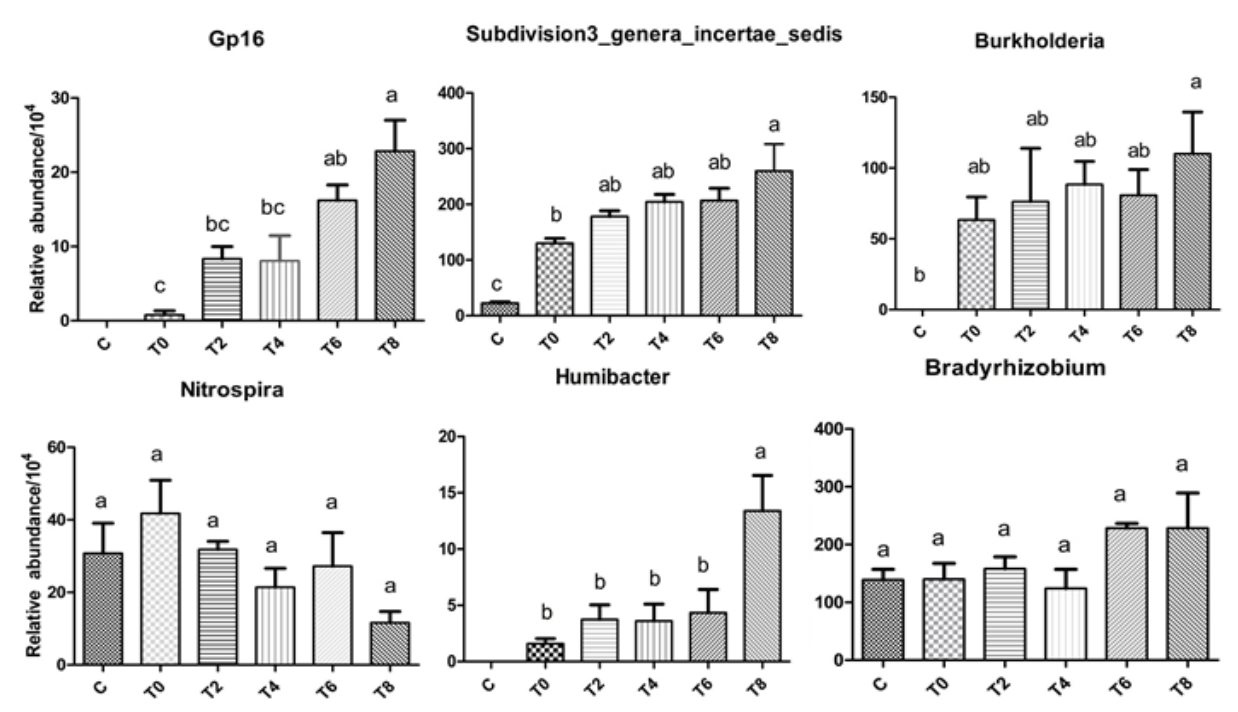

21 Figure 4. The changes of relative abundance of some bacterial genus in the citrus rhizospheric soil under 22 different times of mancozeb application. 